\title{
Polymorphism analysis of the hsp70 stress gene in Broiler chickens (Gallus gallus) of different breeds
}

\author{
Carmen Maria Mazzi ${ }^{1}$, Jesus Aparecido Ferro ${ }^{1}$, Maria Inês Tiraboschi Ferro ${ }^{1}$, Vicente José Maria Savino ${ }^{2}$, \\ Antonio Augusto Domingos Coelho ${ }^{2}$ and Marcos Macari ${ }^{3}$ \\ ${ }^{1}$ Universidade Estadual Paulista, Faculdade de Ciências Agrárias e Veterinárias, \\ Departamento de Tecnologia, Jaboticabal, SP, Brazil. \\ ${ }^{2}$ Universidade de São Paulo, Escola Superior de Agricultura "Luiz de Queiroz”, \\ Departamento de Zootecnia, Piracicaba, SP, Brazil. \\ ${ }^{3}$ Universidade Estadual Paulista, Faculdade de Ciências Agrárias e Veterinárias, Departamento de \\ Morfologia e Fisisologia Animal, Jaboticabal, SP, Brazil.
}

\begin{abstract}
The promoter region and the beginning of the coding region of the $h s p 70$ stress gene were analysed in broiler chickens of a commercial breed (Hubbard-Pettersen), a breed selected for weight gain (PP1) and a non-selected breed (naked-neck Label Rouge). The naked neck gene (Naked neck, $\mathrm{Na}$ ), which reduces feathering in birds and is thus related to heat resistance, was present in both PP1 and Label Rouge breeds. Genomic DNA was restricted with $P s t l$ and Southern blotting analysis of the samples revealed the absence of polymorphic sites for that enzyme in the promoter region and beginning of the coding region of the $h s p 70$ gene of studied birds. PCR-SSCP analysis of these regions, however, indicated the presence of polymorphisms in the beginning of the coding region and the sequencing of the PCR products confirmed and identified two polymorphic sites in this region: a transition $A \rightarrow G$ in position +258 and a transversion $C \rightarrow G$ in position +276 . Both mutations were considered to be silent, since they did not modify the aminoacid sequence of the protein Hsp70. The promoter region of the $h s p 70$ gene was identical in all studied birds, indicating that the regulation pattern of this gene must be the same in all birds at the promoter region. Three different alleles ( $h s p 70-1, h s p 70-2$ and $h s p 70-3$ ) were identified for the $h s p 70$ gene from the observed mutations. The allele $h s p 70-3$ was detected in only two breeds, Hubbard-Pettersen and PP1, but at a low frequency $(0,016$ and 0,006 , respectively).
\end{abstract}

Key words: broiler chickens, hsp 70 gene, naked neck ( $\mathrm{Na}$ ) gene, polymorphism, SSCP.

Received: November 29, 2002; Accepted: May 29, 2003.

\section{Introduction}

Heat stress in birds is one of the major concerns in the poultry industry, since it causes high mortality and/or low productivity, especially during the hot season. The introgression of the gene naked neck $(\mathrm{Na})$ in bird breeds seems to improve the resistance of the birds to heat. The introduction of this gene in commercial breeds might contribute to the production of birds with high genetic potential that show better performance at high temperatures. The correlation between the presence of the $\mathrm{Na}$ gene and the resistance to heat stress is due to the fact that this gene reduces feathering by about $20 \%$ in heterozygote birds

Send correspondence to Maria Inês Tiraboschi Ferro. UNESP, Faculdade de Ciências Agrárias e Veterinárias de Jaboticabal, Departamento de Tecnologia, Via de acesso Prof. Paulo Donato Castellane s/n, 14884-900 Jaboticabal, SP, Brazil. E-mail: mitferro@fcav.unesp.br.
$(\mathrm{Na} / \mathrm{na})$ and $40 \%$ in homozygote birds $(\mathrm{Na} / \mathrm{Na})$. Eberhart and Washburn (1993) stated that feathering reduction in naked neck birds probably caused their greater ability in dissipating heat in exposed areas, which was later confirmed by Yahav et al. (1998). Naked neck birds from a breed selected for weight gain (PP1) and heterozygote for the $\mathrm{Na}$ gene showed lower mortality and weight loss during severe gradual heat stress $\left(28-42^{\circ} \mathrm{C}\right)$ when compared to normally feathered birds (Mazzi, 1998).

Physiologists and geneticists have shown a great interest in a specific response seen in all live organisms when submitted to any kind of stress. The main characteristic during this specific response to stress is the increased expression of the so-called stress proteins (Hsps), especially Hsp70, which has been shown to be one of the most conserved stress proteins. Besides its role in cytoprotection, this protein is also considered a cellular thermometer (Craig and Gross, 1991). 
Since birds are constantly challenged by heat stress in hot countries, many studies involving Hsp70 expression in broilers have been made. Gabriel (1996) showed that the expression of Hsp70 in the hepatocytes of broiler chickens submitted to heat stress is heat- and time-dependent. A positive correlation was seen between the change in cloacal temperature and Hsp70 levels in the liver of naked neck birds at five days of age (Dionello, 1998). Hsp70 expression was also shown to be tissue-dependent when the levels of this protein were studied in different organs of chicken embryos subjected to heat stress (Givisiez et al., 2001). Naked neck birds, from a breed selected for weight gain (PP1), showed different Hsp70 levels in hepatic cells when submitted to increasing gradual heat stress $\left(28-36^{\circ} \mathrm{C}\right)$. Furthermore, the birds that were more resistant to heat $(\mathrm{Na} / \mathrm{na})$ had lower Hsp70 levels when compared to dominant homozygote PP1 birds ( $\mathrm{Na} / \mathrm{Na}$ ), and also to normally feathered birds (na/na) from the same breed (Mazzi et al., 2002). Mahmoud (2000) analysed the $h s p 70$ gene in birds submitted to heat stress and found polymorphic sites located upstream from the coding region. The birds that were more resistant to heat showed only one Pst $\mathrm{I} h \mathrm{sp} 70$ allele of $6.48 \mathrm{~kb}$, whereas the other breeds showed two different alleles for that gene. According to these data, it was concluded that polymorphisms in the $h s p 70$ gene might be used by commercial breeders to produce birds that are more tolerant to heat.

The present study analysed the sequence of the promoter region and the beginning of the coding region of the hsp70 gene in birds from a breed selected for weight gain (PP1) showing three genotypes for $\mathrm{Na}$ gene $(\mathrm{Na} / \mathrm{Na}, \mathrm{Na} / \mathrm{na}$ and $n a / n a$ ), and one commercial normally-feathered breed (Hubbard-Pettersen) and one non-selected breed that was heterozygous for $\mathrm{Na}$ gene (non-selected Label Rouge) were also included. The objective was to evaluate the presence of polymorphism in these regions of the $h s p 70$ gene. The existence of polymorphisms opens up the possibility that one of them might be associated to the phenotype that shows more tolerance to heat.

\section{Material and Methods}

\section{Birds}

This study used thirty birds of the Hubbard-Pettersen commercial breed, thirty naked-neck birds $(\mathrm{Na} / \mathrm{na})$ of the non-selected Label Rouge breed and ninety birds of the experimental breed PP1, thirty of each genotype $(\mathrm{Na} / \mathrm{Na}$, $\mathrm{Na} / \mathrm{na}$ and $n a / n a)$.

\section{Genomic DNA extraction}

Blood samples $(1 \mathrm{~mL})$ were collected in syringes containing $100 \mu \mathrm{L}$ EDTA (0.5 M, pH 8.0). Genomic DNA was obtained from $50 \mu \mathrm{L}$ of blood using microcentrifuge tubes containing $800 \mu \mathrm{L}$ of cold TKM buffer (1 M Tris-HCl; $1 \mathrm{M}$ $\mathrm{KCl} ; 1 \mathrm{M} \mathrm{MgCl} ; 0.1 \mathrm{M}$ EDTA; $1 \mathrm{M} \mathrm{NaCl}$ ). Fifty microlitres of $10 \%$ SDS pre-warmed to $37^{\circ} \mathrm{C}$ were added and the samples were incubated in water bath at $55^{\circ} \mathrm{C}$ for $30 \mathrm{~min}$. After $300 \mu \mathrm{L}$ of $6 \mathrm{M} \mathrm{NaCl}$ were added, the samples were gently homogenised and centrifuged at 14,000 rpm for $20 \mathrm{~min}$, at room temperature. The supernatant from each microtube was transferred to test tubes containing $5 \mathrm{~mL}$ cold $100 \%$ ethanol. The tubes were gently inverted until the DNA could be visualised, which was then recovered with a Pasteur pipette, transferred to a fresh microtube and washed with cold ethanol at $70 \%$. After centrifugation at $14,000 \mathrm{rpm}$ for $4 \mathrm{~min}$, the DNA was air-dried for $5 \mathrm{~min}$ and then dissolved in $1 \mathrm{~mL}$ TE $(10 \mathrm{mM}$ Tris- $\mathrm{HCl} \mathrm{pH} 8.0 ; 1 \mathrm{mM}$ EDTA). The absorbance of the samples was determined at 260 and $280 \mathrm{~nm}$ using a Hitachi spectrophotometer (Model U-2000) and the DNA concentration was calculated (Sambrook et al., 1989).

\section{Restriction with Pstl and Southern Blotting}

Six pools of genomic DNA (five birds/pool) were prepared for each studied group. The pools contained $6 \mu \mathrm{g}$ DNA and were digested with the restriction enzyme PstI (Gibco-BRL) for $8 \mathrm{~h}$ at $37^{\circ} \mathrm{C}$. The samples were then separated by electrophoresis in a $1 \%$ agarose gel for $6 \mathrm{~h}$, at $50 \mathrm{~V}$. After electrophoresis, the gels were left in $0.2 \mathrm{~N} \mathrm{HCl}$ for $10 \mathrm{~min}$, washed rapidly using Milli-Q water and then immersed in a denaturing solution $(0.5 \mathrm{~N} \mathrm{NaOH} ; 1.5 \mathrm{M} \mathrm{NaCl})$ for $20 \mathrm{~min}$. This procedure was done twice to assure DNA denaturation and the gels were washed once more with Milli-Q water and immersed in a neutralising solution (1 M Tris-HCl pH 7.5; $1.5 \mathrm{M} \mathrm{NaCl}$ ) for $20 \mathrm{~min}$. The DNA was transferred from the gel to nylon membranes (Immobilon$\mathrm{Ny}+$; SIGMA, N-8522) by Southern Blotting (Sambrook et al., 1989). After transference, the membranes were washed for $5 \mathrm{~min}$ with a wash solution $(0.1 \mathrm{X} \mathrm{SSC} ; 0.1 \%$ SDS; $50 \mathrm{mM}$ Tris-HCl pH 7.5) and, shortly after, crosslinked at $160,000 \mu \mathrm{J} / \mathrm{cm}^{2}$ to fix the DNA to the membrane. The membranes were placed in hybridisation bottles and $30 \mathrm{~mL}$ of pre-hybridisation solution (6X SSC; 10X Denhardt's reagent; $1 \%$ SDS; $250 \mu \mathrm{g}$ denatured salmon sperm DNA $/ \mathrm{mL}$ ) was added. The bottles were placed in a hybridisation oven (HYBAID Instruments) at $65^{\circ} \mathrm{C}$ for $2 \mathrm{~h}$. The pre-hybridisation solution was discarded and $15 \mathrm{~mL}$ of pre-warmed hybridisation solution (6X SSC; $1 \%$ SDS, $65{ }^{\circ} \mathrm{C}$ ) was added with $10 \mu \mathrm{L}$ of probe labelled with ${ }^{32} \mathrm{P}-\mathrm{dCTP}$ by random priming (Feinberg and Volgestein, 1983). The probe was a DNA fragment specific for the chicken $h s p 70$ gene, amplified using the primers Hsp70-F1 and Hsp70-R3 (Table 1). The fragment length was 554 bp and it comprised both the promoter and the beginning of the coding region of $h s p 70$ gene. After $16 \mathrm{~h}$ of hybridisation, the solution was changed to $50 \mathrm{~mL}$ of washing solution 1 (2X SSC, $0.1 \%$ SDS), pre-warmed to $65^{\circ} \mathrm{C}$. The membranes were washed twice for 20 min using washing solution 2 ( $\left.0.1 \mathrm{X} \mathrm{SSC} ; 0.1 \% \mathrm{SDS}, 65^{\circ} \mathrm{C}\right)$. Sheets of X-Ray film 
Table 1 - Primers used on PCR amplification of the chicken $h s p 70$ gene.

\begin{tabular}{llc}
\hline Primers & Sequence & Position on reference sequence \\
\hline Hsp70-F1 & 5'GAGTGGCGCAGCGTAGAAAG 3' & 18 \\
Hsp70-F2 & 5'GATTGGTCCTTAGCGTTCTGGC 3' & 208 \\
Hsp70-F3 & 5'TCATCATGTCTGGCAAAGGG 3' & 387 \\
Hsp70-F4 & 5'AACCGCACCACACCCAGCTATG 3' & 497 \\
Hsp70-F19 & 5'CAACAGAGATAGGGTGGGAG 3' & 1993 \\
Hsp70-R1 & 5'TTCCTCTTGGTCAGTCAGCC 3' & 382 \\
Hsp70-R2 & 5'TGATCTCCACTTTGCCATGCTG 3' & 479 \\
Hsp70-R3 & 5'CACTTGGTTCTTGGCAGCATC 3' & 571 \\
Hsp70-R3b & 5'CTGGGAGTCGTTGAAGTAAGCG 3' & 856 \\
Hsp70-R24 & 5'TGCCTTTATACACACCCAACAG 3' & 2426 \\
\hline
\end{tabular}

The letters $\mathrm{F}$ and $\mathrm{R}$ in primer names refer to their orientation (forward and reverse, respectively).

were exposed to the membranes using adequate cassettes for $72 \mathrm{~h}$ at $-70{ }^{\circ} \mathrm{C}$ and developed.

\section{PCR amplification of the chicken hsp70 gene}

The chicken $h s p 70$ gene sequence deposited in GenBank under the accession number J02579 (Morimoto et al., 1986) was called the reference sequence in the present study. The Gene Runner software (version 3.0) was used to design primers from this sequence (Table 1). The primers were used in PCR reactions to amplify specific regions of the $h s p 70$ gene, and reactions were assembled using the following combination of components: $1 \mathrm{X}$ Taq reaction buffer (Gibco-BRL), 0.2 pmol primer F, 0.2 pmol primer R, $0.1 \mathrm{mM}$ dNTPs, $2 \mathrm{mM} \mathrm{MgCl}_{2}, 100$ ng genomic DNA and 1 unit Taq DNA polymerase (Gibco-BRL) to a final volume of $30 \mu \mathrm{L}$.

The following regions of the $h s p 70$ gene were amplified: F1-R1 (364 bp), F2-R2 (271 bp), F3-R3 (184 bp), F4-R3b (359 bp) and F19-R24 (433 bp). The PCR program for F1-R1 was: initial denaturing at $95{ }^{\circ} \mathrm{C}$ for $2 \mathrm{~min}$ and 35 cycles of $95{ }^{\circ} \mathrm{C}$ for $1 \mathrm{~min}$ (denaturing), $60{ }^{\circ} \mathrm{C}$ for $1 \mathrm{~min}$ (primer annealing) and $72{ }^{\circ} \mathrm{C}$ for $1 \mathrm{~min}$ and $30 \mathrm{~s}$ (extension by Taq). The other reactions used similar PCR programs, but annealing temperatures were $65,64.5,64.5$ and $61.5^{\circ} \mathrm{C}$, respectively. The positions of the primers in the $h s p 70$ gene sequence are shown in Figure 1.

\section{SSCP analysis}

After visualisation of the amplification products in agarose gel (1\%), a 3- $\mu \mathrm{L}$ aliquot of each sample was diluted in $6 \mu \mathrm{L} \mathrm{SSCP} \mathrm{buffer} \mathrm{(95 \%} \mathrm{formamide;} 20 \mathrm{mM}$ EDTA; $0.05 \%$ bromophenol blue; $0.05 \%$ xylene-cyanol). The samples were then denatured for $10 \mathrm{~min}$ at $95^{\circ} \mathrm{C}$ and incubated in ice for the same period before electrophoresis in a nondenaturing acrylamide:bis-acrylamide (49:1) gel, using the Bio-Rad mini-protean II system. The gels were composed of $600 \mu \mathrm{L} 10 \mathrm{X}$ TBE (0.9 M Tris; $0.02 \mathrm{M}$ EDTA; $0.9 \mathrm{M}$ boric acid), acrylamide:bis (49:1) up to the desired concentra-

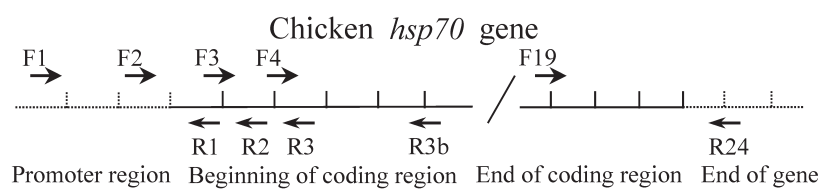

Figure 1 - Schematic representation of the position of the primers that were used in PCR-SSCP for detection of polymorphisms in the chicken hsp70 gene.

tion, $60 \mu \mathrm{L} 10 \%$ APS and $6 \mu \mathrm{L}$ TEMED and Milli-Q water (qsp $6 \mathrm{~mL}$ ). Both the concentration of acrylamide and the running time were standardised for each analysed PCR product (15\% for F1-R1, F2-R2 and F4-R3b; 20\% for F3-R3 and 12\% for F19-R24). The gels were silver-stained according to Bassan et al. (1991) so that the bands could be visualised.

\section{Sequencing of the PCR products}

In order to obtain the sequence of the promoter region and the beginning of the coding region of $h s p 70$ gene, the sequences F1-R2 (461bp) and F2-R3b (648 bp) were amplified for all birds using the primers shown in Table 1 . The final volume of these reactions was $50 \mu \mathrm{L}$ and the reagents were added as follows: $100 \mathrm{ng}$ genomic DNA, $0.2 \mathrm{pmol}$ primer F; 0.2 pmol primer $\mathrm{R} ; 2 \mathrm{mM} \mathrm{MgSO}_{4}, 0.1 \mathrm{mM}$ dNTP and one unit High Fidelity Taq DNA Polymerase (Invitrogen). The PCR program consisted of an initial denaturing $\left(95^{\circ} \mathrm{C}\right)$ for $2 \mathrm{~min}$ and 35 cycles of $95^{\circ} \mathrm{C}$ for $1 \mathrm{~min}$, $62.5^{\circ} \mathrm{C}$ and $62{ }^{\circ} \mathrm{C}$ for $1 \mathrm{~min}$ (annealing of primer pairs $\mathrm{F} 1-\mathrm{R} 2$ and F2-R3b, respectively) and $68{ }^{\circ} \mathrm{C}$ for $1 \mathrm{~min}$ and $30 \mathrm{~s}$ (extension by Taq). Once the amplification was confirmed in $1 \%$ agarose gel, the PCR products were purified using the Concert ${ }^{\mathrm{tm}}$ Rapid PCR Purification System Kit (Gibco-BRL). An aliquot of the purified product was used for quantification in $1 \%$ agarose gel and approximately 50-100 ng of the products were used for sequencing in a reaction with sequencing buffer $(0.5 \mathrm{X}), 2 \mu \mathrm{L}$ of Big Dye (version 3), 5 pmol of primer $\mathrm{F}$ or $\mathrm{R}$ and sterile water to a final 
volume of $10 \mu \mathrm{L}$. After 35 reaction cycles $\left(95^{\circ} \mathrm{C}\right.$ for $1 \mathrm{~min}$; $62.5^{\circ} \mathrm{C}$ for $1 \mathrm{~min}$ and $72{ }^{\circ} \mathrm{C}$ for $1 \mathrm{~min} 30 \mathrm{~s}$ ), the samples were washed with $80 \mu \mathrm{L}$ of $75 \%$ isopropanol for $15 \mathrm{~min}$ and centrifuged at $4,500 \mathrm{rpm}$ for $25 \mathrm{~min}$ at $20^{\circ} \mathrm{C}$. The samples were washed using $200 \mu \mathrm{L}$ of $70 \%$ ethanol and centrifuged at $4,500 \mathrm{rpm}$ for $15 \mathrm{~min}$ at $20^{\circ} \mathrm{C}$. The samples were then vacuum dried and loaded to a polyacrylamide gel in the ABI-377 DNA sequencer (Perkin Elmer).

\section{Results}

The results of Southern Blotting analysis of the total DNA digested with Pst $\mathrm{I}$ and hybridised with the probe specific for the chicken $h s p 70$ gene showed no sites for PstI in the promoter region or the beginning of the coding region of the $h s p 70$ gene. One single $6 \mathrm{~kb}$ fragment hybridised with the probe in all animals (data not shown).

The PCR products F1-R1, F2-R2, F3-R3 and F19R24 did not show any difference in their migration patterns in polyacrylamide gels when submitted to SSCP analysis. Nevertheless, different migration patterns in polyacrylamide gels were seen when F4-R3b fragments were analysed using this technique (Figure 2), indicating that this region (beginning of coding region) presents polymorphisms.

Data from sequencing of the promoter region and the beginning of the coding region of the $h s p 70$ gene were in accordance with the observations obtained by SSCP analysis of these regions. In all birds, the nucleotide sequence of the $h s p 70$ promoter region was identical. On the other hand,

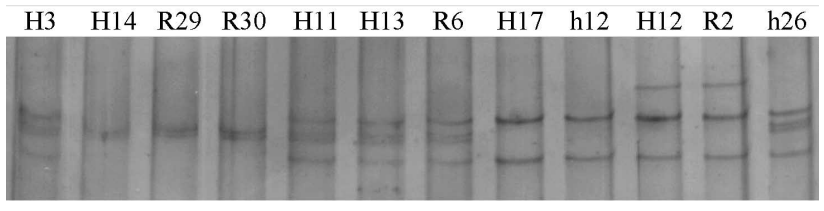

Figure 2 - Migration pattern of F4-R3b hsp70 fragment (359 bp) in acrylamide gel for some DNA chicken samples. H - Hubbard, R - PP1 na/na and h - PP1 Na/na.

at the beginning of the coding region, two polymorphic sites were found: one transition $\mathrm{A} \rightarrow \mathrm{G}$ on position +258 and one transversion $\mathrm{C} \rightarrow \mathrm{G}$ on position +276 . Polymorphic sequences were submitted to BLASTx from NCBI and the two polymorphic sites were considered as silent mutation sites, since they did not cause a change in the aminoacid sequence of the $H s p 70$ protein.

The polymorphisms found here and the combinations between them in the constitution of the genotype of the birds indicated the presence of three alleles for the chicken $h s p 70$ gene, which were called $h s p 70-1, h s p 70-2$ and hsp70-3. The nucleotide sequences of the three alleles were deposited in the GenBank with accession numbers AY178441, AY178442 and AY178443 for hsp70-1, $h s p 70-2$ and $h s p 70-3$, respectively.

One alignment of the three alleles using the software Clustal W is shown on Figure 3; differences among them only occur in positions +258 and +276 . Figure 3 also shows the alignment between the three sequences and the reference sequence (Morimoto et al., 1986). Some changes in the nucleotide sequences may be observed, specially in the

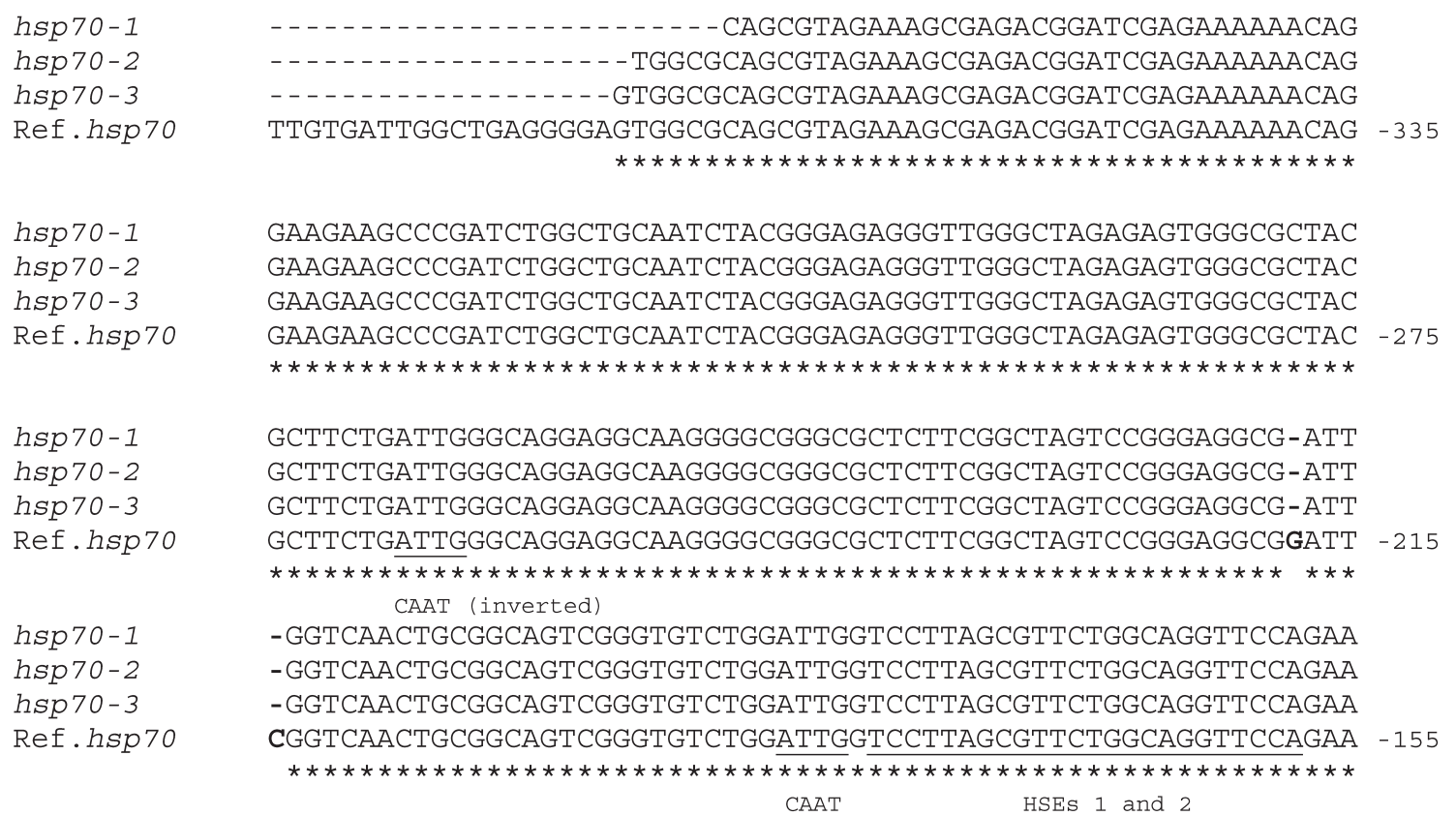

Figure 3 - Alignment (CLUSTALW) of alleles $h s p 70-1$, hsp70-2 and hsp70-3 with the reference sequence (J02579 - Morimoto et al., 1986). Underlined: conserved regions CAAT, HSEs 1 and 2, TATA box and initial ATG; in bold: transitions and transversions seen among the three alleles and the reference hsp 70 gene. 


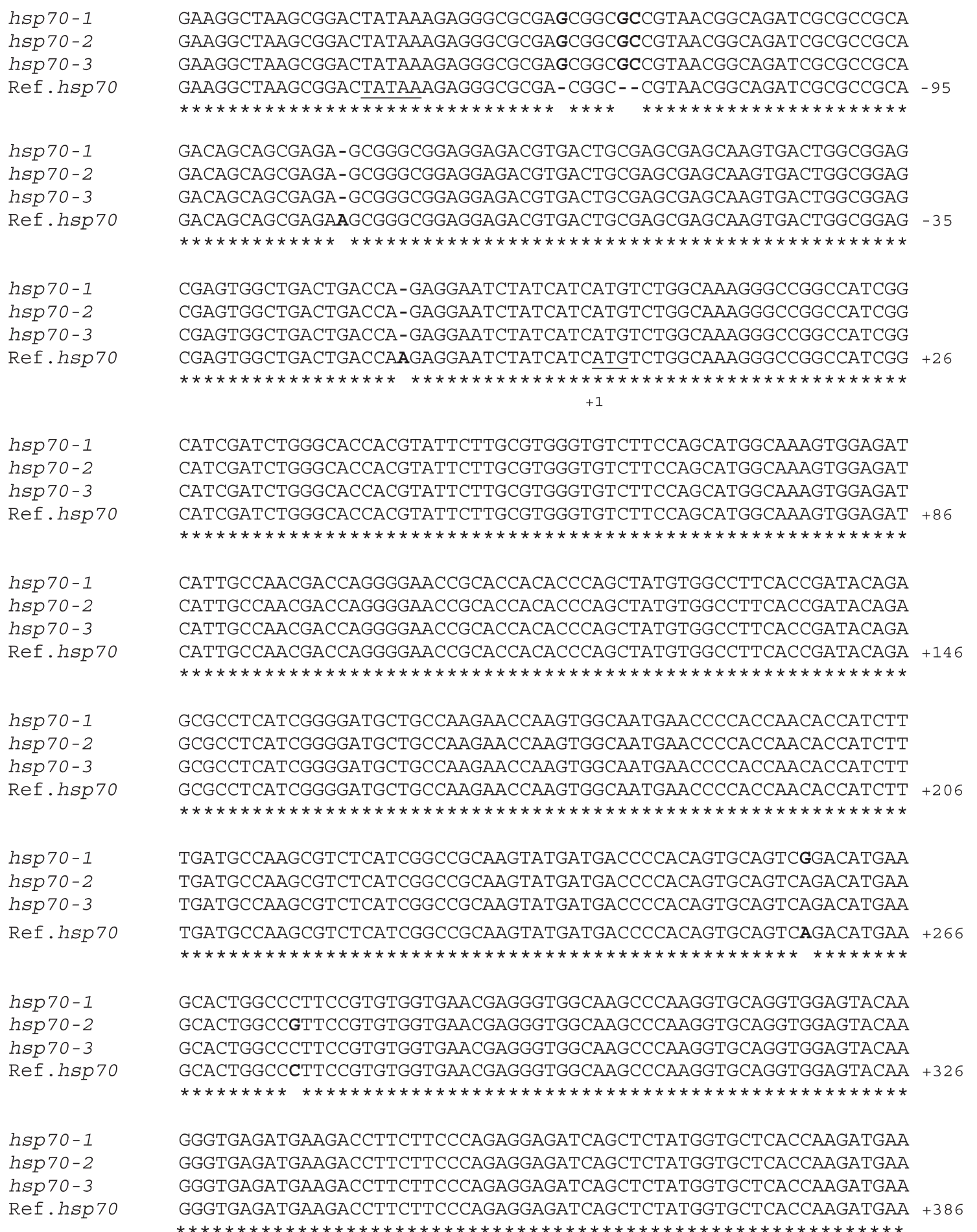

Figure 3 (Cont.)

promoter region: a $\mathrm{G}$ deletion on position -218 , a C deletion on position -214 , two $\mathrm{G}$ insertions on positions -123 and -118 , one $\mathrm{C}$ insertion on position -117 and two A deletions on positions -81 and -16 . When the three alleles were compared to the reference sequence, it was observed that on positions +258 and +276 , where the polymorphism occurs in the studied population, the allele $h s p 70-3$ showed nucleotides that are identical to the reference sequence, i.e., one nucleotide A (+258) and one C (+276).

The frequencies of each allele within the populations are presented in Table 2. The hsp70-1 allele had the highest frequency in all groups of birds when compared to the other 
Table 2 - Allelic and genotypic frequencies observed for each breed ( $\mathrm{n}=30$ for Hubbard and Label Rouge and $\mathrm{n}=90$ for PP1).

\begin{tabular}{|c|c|c|c|c|c|}
\hline \multirow[t]{2}{*}{ Breed } & \multicolumn{3}{|c|}{ Alleles } & & \\
\hline & hsp70-1 & hsp 70-2 & hsp 70-3 & & \\
\hline Hubbard & 0.633 & 0.35 & 0.016 & & \\
\hline PP1 & 0.82 & 0.15 & 0.006 & & \\
\hline \multirow[t]{3}{*}{ Label Rouge } & 0.683 & 0.316 & - & & \\
\hline & \multicolumn{5}{|c|}{ Genotypes } \\
\hline & hsp 70-1/hsp70-1 & hsp 70-2/hsp 70-2 & hsp $70-1 / h s p 70-2$ & hsp 70-1/hsp70-3 & hsp70-2/hsp 70-3 \\
\hline Hubbard & 0.33 & 0.03 & 0.60 & - & 0.03 \\
\hline PP1 & 0.67 & 0.08 & 0.20 & 0.03 & 0.01 \\
\hline Label Rouge & 0.34 & - & 0.63 & - & - \\
\hline
\end{tabular}

alleles. A low frequency of the hsp70-3 allele was seen in populations PP1 (0.006) and Hubbard (0.016), while this allele was not seen in the non-selected Label Rouge population. Table 2 also shows the frequency of the five different genotypes observed in the populations. The highest frequency of the $h s p 70-1 / h s p 70-1$ genotype was seen in PP1 breed, whereas the commercial (Hubbard) and nonselected (Label Rouge) populations showed a higher frequency of the $h s p 70-1 / h s p 70-2$ genotype. The other genotypes had a low frequency, and the hsp70-1/hsp 70-3 genotype was seen only in the population PP1. Only the hsp70-1/hsp70-1 and hsp70-1/hsp70-2 genotypes were seen within the Label Rouge population, while the other groups presented at least three different genotypes. The values from the chi-square $\left(\chi^{2}\right)$ test for genotype frequencies found here indicated that all were in equilibrium (Hubbard $=0,3, \mathrm{p}>0,05 ; \mathrm{PP} 1 \mathrm{Na} / \mathrm{Na}=0,002, \mathrm{p}>0,05 ; \mathrm{PP} 1 \mathrm{Na} /$ na $=$ $0,33 \mathrm{p}>0,05 ;$ PP1 na/na $=0,022, \mathrm{p}>0,05 ;$ Label Rouge $=$ $0,093, \mathrm{p}>0,05)$.

\section{Discussion}

The absence of restriction sites for the PstI enzyme in the promoter region and the beginning of the coding region of the $h s p 70$ gene in the birds evaluated in this study is a different result from that reported by Mahmoud (2000), who found three different allelic fragments for the chicken hsp70 gene when genomic DNA was restricted using PstI. The author also observed the presence of an hsp70 PstI allele of $6.48 \mathrm{~kb}$ in the birds that were more resistant to heat, and concluded that the polymorphisms in the $h s p 70$ gene exist in different bird populations and that it is possible that these polymorphisms might be used by commercial breeders to produce more tolerant birds.

Polymorphisms in the hsp 70 gene with PstI were also observed in other species, such as pigs (Ruohonen-Lehto et al., 1993). Likewise, in patients with SLE (Systemic Lupus Erythematosus), a higher frequency was observed of the 8.5-kb PstI allele of the gene hsp70-2, which is heatinducible, while normal individuals had a higher frequency of the common 9-kb allele of hsp70-2. The presence of the polymorphic allele $(8.5 \mathrm{~kb})$ was associated with SLE susceptibility (Jarjour et al., 1996). A frequency of $21.8 \%$ was observed for the hsp70-2/PstI allele in patients with MLV (Mediterranean Visceral Leishmaniosis), whereas normal individuals showed a $12.6 \%$ frequency of this allele (Meddeb-Garnaoui et al., 2001). The same PstI allele of $8.5 \mathrm{~kb}$ was also associated with susceptibility to insulindependent diabetes mellitus (IDDM, Chuang et al., 1996).

Different restriction patterns of the enzymes Hinfl and Scal were observed for the $h s p 70$ gene in Cryptosporidium parvum (Gobet and Toze, 2001); of EcoRI, BamHI, DraI, SalI and HindIII in nematodes (Hashmi et al., 1997); of BamHI and ClaI in Drosophyla (Zatsepina et al., 2001), of the PvuII enzyme in pigs (Ruohonen-Lehto et al., 1993), and of the BamHI enzyme in humans susceptible to hypertension (Hamet et al., 1994).

The absence of polymorphisms in the promoter region of the $h s p 70$ gene in the studied birds seems to indicate that this gene presents the same regulation pattern for this region in the different bird populations. Considering these observations, the differential expression of Hsp70 protein reported for PP1 birds submitted to graded heat stress of 28 to $36{ }^{\circ} \mathrm{C}$ (Mazzi et al., 2002) does not seem to be related to the presence of polymorphisms in the promoter region of hsp 70 gene.

Zhang et al. (2002) detected, by PCR-SSCP and sequencing, polymorphism in regulatory and coding regions of the $h s p 70$ gene in chickens with different heat tolerance capability. Huang et al. (2002) detected single nucleotide polymorphisms (SNPs) in the 5' flanking region of the hsp70-2 gene in boars. These SNPs have been associated with the quality of semen production during the summer and can, also, be used as markers for semen quality selection in these animals.

In our study, PCR-SSCP techniques were effective in revealing different genotypes of birds in the studied populations. Gasser et al. (2001) were also able to detect different Cryptosporidium parvum genotypes in diverse hosts using the same techniques. 
The alignment of the three alleles ( $h s p 70-1, h s p 70-2$ and $h s p 70-3$ ) detected in the present study and the $h s p 70$ gene sequence of Morimoto et al. (1986), considered as a reference sequence (Figure 3), revealed that among the three alleles, $h s p 70-3$ is the most similar to the reference gene, indicating that this allele must be the older within the population. The alterations seen in the promoter region of the alleles when compared to the reference sequence did not affect any critical regulatory regions such as the heat shock elements (HSE 1 and HSE 2), positioned at -170 to -158 and -180 to -166 , respectively, where the transcription factors (HSFs) bind during the activation of the gene. The regions CAAT (-116 and -267) and TATA box (-139) were not affected by point mutations either.

\section{Acknowledgments}

The authors thank the Conselho Nacional de Desenvolvimento Científico e Tecnológico (CNPq) and Fundação de Amparo à Pesquisa do Estado de São Paulo (FAPESP) for financial support.

\section{References}

Bassan BJ, Anollés GCE and Gresshoff PM (1991) Fast and sensitive silver staining of DNA in polyacrilamide gels. An Biochem 196:80-3.

Chuang LM, Jou TS, Wu HP, Tai TY and Lin BJA (1996) Rapid method to study heat shock protein 70-2 gene polymorphism in insulin-dependent diabetes mellitus. Pancreas 13:268272.

Craig EA and Gross CA (1991) Is $h s p 70$ the cellular thermometer? TIBS 16:135-40.

Dionello NJL (1998) Efeito do estresse calórico agudo em frangos de corte (2-5 dias de idade) sobre a síntese da proteína de choque térmico de $70 \mathrm{kD}$ (Hsp 70) e de seu RNA mensageiro emtecido hepático e cerebral. Thesis, Universidade Federal de Pelotas, Rio Grande do Sul.

Eberhart DE and Washburn KW (1993) Assessing the effects of the naked neck gene on chronic heat stress resistance in two genetic populations. Poult Sci 72:1391-9.

Feinberg AP and Volgestein BA (1983) A technique for radiolabeling DNA restriction endonuclease fragments to high specific activity. Anal Biochem 132:6-13.

Gabriel JE, Ferro JA, Stefani RMP, Ferro MIT, Gomes SL and Macari M (1996) Effect of acute heat stresson the heat shock protein 70 messenger RNA on the heat shock protein expression in the liver of broilers. Br Poult Sci 37:443-9.

Gasser RB, Zhu X, Cacio S, Chalmers R, Widmer G, Morgan UM, Andrew-Thompson RC, Pozio E and Bowning GF (2001) Genotyping Crypstosporidium parvum by single-strand conformation polymorphism analysis of ribossomal and heat shock gene regions. Electrophoresis 22:433-7.

Givisiez, PEN, Silva MM, Mazzi CM, Ferro MIT, Ferro JA, Gonzalez E and Macari M (2001) Heat or cold chronic stress affects organ weights and Hsp70 levels in chicken embryos. Can J Anim Sci 82:83-7.

Gobet P and Toze S (2001) Sensitive Genotyping of Cryptosporidium parvum by PCR-RFLP Analysis of the 70-kilodalton Heat Shock Protein $(H s p 70)$ Gene. FEMS Microb Letters 200:37-41.

Hamet P, Sun YL, Malo D, Kong D, Kren V, Pravenec M, Kunes J, Dumas P, Richard L and Gagnon F (1994) Genes of stress in experimental hypertension. Clin Exp Pharmacol Physiol 21:907-11.

Hashmi G, Hashmi S, Selvan S, Grewal P and Gaugler R (1997) Polymorphism in Heat Shock Protein Gene ( $h s p 70)$ in Entomopathogenic Nematodes (Rhabditida). J Therm Biol 22:143-9.

Huang SY, Chen MY, Lin EC, Tsou HL, Kuo YH, Ju CC and Lee WC (2002) Effects of single nucleotide polymorphisms in the 5'- flanking region of heat shock protein 70.2 gene on semen quality in boars. Anim Reprod Sci70:99-109.

Jarjour W, Reed AM, Gauthier J, Hunt SIII and Winfiel JB (1996) The 8.5-kb PstI Allele of the Stress Protein Gene, Hsp70-2. Human Immunology 45:59-63.

Mahmoud Kamel (2000) Genetic and environmental variations of chicken heat shock proteins. PhD Thesis, North Carolina State University, North Carolina.

Mazzi CM (1998) Análise da expressão da proteína de estresse Hsp70 em frangos de corte portadores do gene "naked neck" (pescoço pelado) submetidos a estresse térmico gradativo. Dissertação, Universidade Estadual Paulista, Jaboticabal, São Paulo.

Mazzi CM, Ferro MIT, Coelho AAD, Savino VJM, Macari M, Ferro JA, Givisiez PEN, Giachetto PF, Silva MM and Dionello NJL (2002) Effect of heat exposure on the thermoregulatory responses of selected naked neck chickens. Arq Bras Med Vet Zootec 54:35-41.

Meddeb-Garnaoui A, Gritli S, Garbouj S, Ben Fadhel M, El Kares R, Mansour L, Kaabi B, Chouchane L, Ben Salah A and Dellagi, K (2001) Association Analysis of HLA-Class II and Class III Gene Polymorphisms in the Susceptibility to Mediterranean Visceral Leishmaniasis. Hum Immunol 62:50917.

Morimoto RI, Hunt C, Huang S, Berg KL and Banerji SS (1986) Organization, Nucleotide Sequence, and Transcription of Chicken HSP70 Gene. J Biol Chem 25:12692-99.

Ruohonen-Lehto MK, Rothschild MF and Larson RG (1993) Restriction fragment length polymorphisms at the heat shock protein Hsp70 gene (s) in pigs. Anim Genet.24:67-8.

Sambrook J, Fritsch EF and Maniatis T (1989) Molecular Cloning: a laboratory manual. 2nd edition. Cold Spring Harbor Press, New York, 2:9.31-57.

Yahav S, Luger D, Cahaner A, Dotan M, Rusal M and Hurwitz S (1998) Thermorregulation in naked neck chickens subjected to different ambient temperatures. Br Poult Sci 39:133-8.

Zatsepina OG, Velikodvorskaia VV, Molodtsov VB, Garbuz D, Lermn DN, Bettencourt BR, Feder ME and Evgenev MB (2001) A Drosophila melanogaster Breed from SubEquatorial Africa has exceptional thermotolerance but decreased Hsp70 expression. J Exp Biol 204:1869-81.

Zhang X, Du H and Li J (2002) Single nucleotide polymorphism of chicken heat shock protein 70 gene. 7 th World Congress on Genetics Applied to Livestock Production, Montpellier, France.

Editor: André Luiz Paranhos Perondini 